\title{
Improved Deformation Behaviour of Groove Square Mild Steel Tube under Compressive Loading
}

\author{
${ }^{1 *}$ Dipen Kumar Rajak, ${ }^{1}$ L. A. Kumaraswamidhas and ${ }^{2}$ S. Das, \\ ${ }^{1}$ Department of Mining Machinery Engineering, \\ Indian School of Mines, Dhanbad, Jharkhand-826004 (INDIA) \\ ${ }^{2}$ Advanced Materials and Processes Research Institute, Bhopal, Madhya Pradesh- 462026, (INDIA)
}

\begin{abstract}
This paper presents, groove square mild steel tube (GSMST) were used to improve energy absorption capacity subjected to axial loading condition. The foam filled thin walled tube was fabricated with GSMST as its shell and closed cell aluminium (Al) alloy LM 30+10wt\% SiCp foam as its core. Aluminium foams were invented by melt route processes using $\mathrm{TiH}_{2}$ as a foaming agent. The energy absorption rate per unit volume was noted that 24.2 to $24.7 \mathrm{MPa}$ and 31.6 to $32.8 \mathrm{MPa}$ empty and foam filled tube sample respectively. This work also describes the compression actions of empty GSMST and filled with foam at a varying strain-rate between 0.01/s to $1 / s$. The axial compression load and energy absorption value of foam filled GSMST were higher than the sum of that of aluminium alloy foam and empty mild steel tube due to the interaction between tube and filler materials.
\end{abstract}

Keywords: Al foams, compression deformation, energy absorption rate, FESEM etc.

\section{Introduction}

Due to lightweight, the closed cell aluminium foams (CCAF) is increased to structural applications in automobile sector ${ }^{[1-2]}$. These foams can be reducing the overall structural weight i.e. vehicle weight, which is directly affect in an increased fuel efficiency and make the eco-friendly environment. The inimitable properties of metallic foams make them desirable for an extensive variety of applications, such as thermal barriers, crash absorber, and noise absorber etc. ${ }^{[3-5]}$. CCAF also have the potential for use in blast mitigation ${ }^{[6-7]}$. Nowadays, increasing demands of passenger safety in automobiles sector and materials recycling make a constructor of using metal foams. On the other hand the foams, including polyurethane and aluminium foams are also being designed and studied for applications in automobile structures for weight reduction and safety improvement ${ }^{[8-9]}$. Open cell aluminium foam is formed by infiltration of polyurethane foam with heat resistant material then after polyurethane is removed by heating and liquid metal is infiltrated through the fine pore. In the past, some metallic foam would have been ruled out for technically or economic reasons ${ }^{[10]}$. But several companies have recently developed processes capable of manufacturing larger numbers of metal foams using molten metal processing systems.

The present study mainly focused on the energy absorption characteristics of empty and foamed filled GSMST. Consideration and suggestion towards energy efficient closed cell aluminium foam structure are made with the mechanical energy absorption characteristics. The compression behaviour and energy absorption capacity under compressive were studied. The present work shows that the energy absorption capacity of empty and foam filled GSMST and foam made by the melt route process at CSIR-Advanced Materials and Processes Research Institute, Bhopal.

\subsection{Aluminium foams}

LM $30 \mathrm{Al}$-alloy contains $4.2 \mathrm{wt} \% \mathrm{Cu}, 0.5 \mathrm{wt} \% \mathrm{Mg}, 0.2 \mathrm{wt} \% \mathrm{Mn}$ and $0.81 \mathrm{wt} \% \mathrm{Fe}, 7.87 \mathrm{wt} \% \mathrm{Si}$, and rest is aluminium (Al). LM30+10wt\% SiCp foam samples were manufacture through the melt route method by AMPRI Bhopal .The porosity of aluminium foam varied from $80 \%$ to $85 \%$ shows in Figure 1 and the cell sizes of aluminium foam varied from 0.8 to $1 \mathrm{~mm}$. 


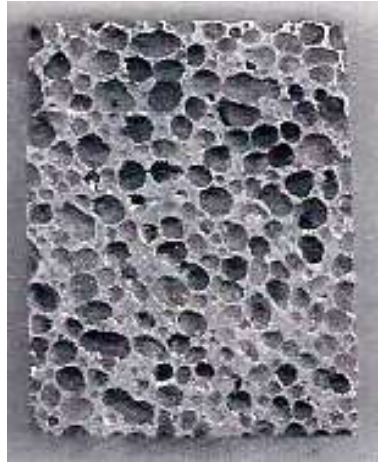

Figure 1: valid porosity varied from 80 to $85 \%$ of aluminium alloy foams

\section{Experimental Procedure}

\subsection{Sample preparation and pore size analysis}

Aluminium alloy (LM30) melt can be foamed by mixing thickening and foaming agent titanium hydride $\left(\mathrm{TiH}_{2}\right) . \mathrm{SiCp}$ is used as thickening agent and $\mathrm{TiH}_{2}$ is used as foaming agent. $\mathrm{TiH}_{2}$ releases hydrogen $\left(\mathrm{H}_{2}\right)$ gas when added in liquid metal. Large volume of hydrogen gas is released, which creates bubbles that lead to foam structure. When foaming is complete, the foam structure is cooled by compressed air and this experiment we have taken LM30+10wt\% SiCp foam and foam sample is cut using a slow speed cutter, cold mounted and polished metallographically using standard polishing technique. Pore size distribution is calculated using material pro software. One face of the sample is scan and uploaded to the material pro software and calculated the pore size. Figure 2(a) scan image of the aluminium foam and (b) the pore size distribution, using Material Pro software around $85 \%$ pores are in the size range of $0.5-2.0 \mathrm{~mm}$ respectively. The foam piece was tightly fitted inside the empty SGT shown in Figure 3 (i.e. 3 (a) and (b)).
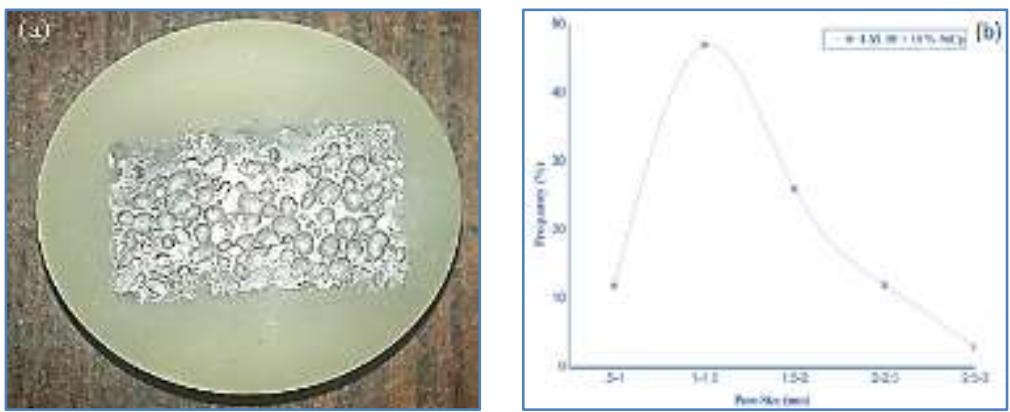

Figure 2: (a) scan image and (b) percentage frequency distribution of cells v/s size of cells of foam.

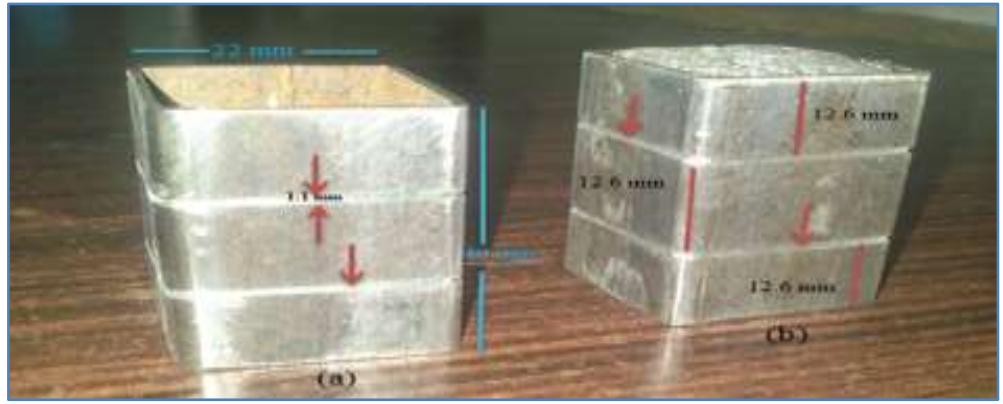

Figure 3: (a) empty and (b) filed of square groove mild steel tube (GSMST) 


\section{Results and Discussion}

\subsection{Compression Test}

Compression test of aluminium foam is performed on a UTM machine at different strain rate $(0.01 / \mathrm{s}$ to $1 / \mathrm{s})$ for compression test, sample of $22 \mathrm{~mm} \times 22 \mathrm{~mm} \times 40 \mathrm{~mm}$ are used. Figure 4 shows the compressive stress versus compressive strain response of the empty and filled GSMST was found to be sensitive to the applied strain rate between $0.01 / \mathrm{s}$ to $1 / \mathrm{s}$. The plateau stresses were found to be similar with a small average increase in level for increasing strain rate.
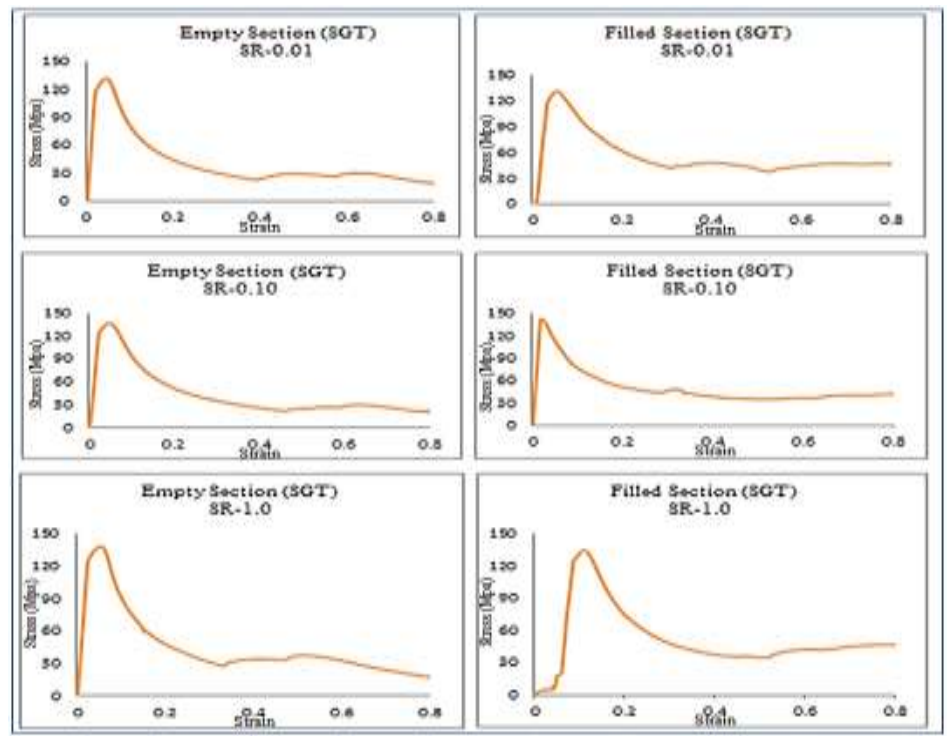

Figure 4: stress-strain curves at various strain rate of empty and foam filled GSMST

The plateau strength of the foam at $0.01 / \mathrm{s}$ to $1 / \mathrm{s}$, shown in Table 1, increased from 24.2 MPa to $24.7 \mathrm{Mpa}$, empty section and 31.6 Mpa to $32.8 \mathrm{Mpa}$, filled section of GSMST.

TABLE I: Plateau stress with different strain rate

\begin{tabular}{|c|c|c|c|c|}
\hline S.No. & $\begin{array}{l}\text { Strain Rate } \\
\quad(/ \mathrm{sec})\end{array}$ & $\begin{array}{c}\text { Empty Section } \\
\text { ( GSMST ) } \\
\text { Plateau Stress } \\
(\mathrm{MPa})\end{array}$ & $\begin{array}{c}\text { Filled Section } \\
\text { ( GSMST ) } \\
\text { Plateau Stress } \\
(\mathrm{MPa})\end{array}$ & $\begin{array}{c}\text { Increased Plateau Stress } \\
(\mathrm{MPa})\end{array}$ \\
\hline 1 & 0.01 & 24.2 & 31.6 & 07.4 \\
\hline 2 & 0.10 & 23.4 & 30.9 & 07.5 \\
\hline 3 & 1.00 & 24.7 & 32.8 & 08.1 \\
\hline
\end{tabular}

\subsection{Microstructure Characterization}

Microstructure analysis, LM30+10wt\% SiCp foam sample is cut from top to bottom portion of the square, prior to the micro-structure analysis, the sample are mechanically polished using standard metallographic practices [5]. The micro-structure of foam samples is analysed using Scanning Electron Microscope (SEM) (Supra 55, Carl Zeiss, Germany). It shows the pores (marked P) and cell wall (arrow marked) and higher magnification micrographs of the cell wall shown in Figure 5 (a). The thickness of the cell wall is measured to be around $100 \mu \mathrm{m}$. Figure 5 (b) shows a SEM micrograph the wall thickness measured to be around $20 \mu \mathrm{m}$ and higher magnification micrograph of cell wall clearly shows SiCp. 

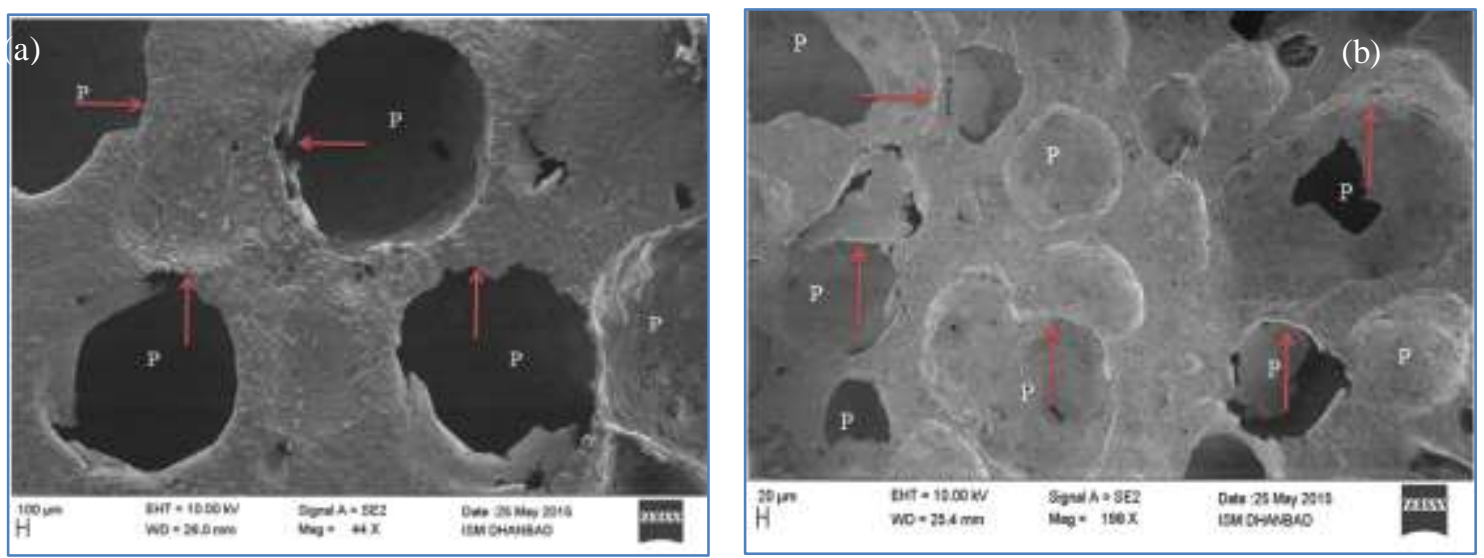

Figure 5: (a) higher magnification micrograph showing cell wall (b) micrograph of the cell wall showing in the aluminium alloy matrix

\section{Conclusion}

The strength property of the empty and filled GSMST has been characterized and its response to quasistatic at various strain rates presented. The energy absorption capacity calculated form the resultant stress strain curves. The quasi-static loading of the aluminium alloy foams material showed the maximum strength increase of all situations. Based on the revision, the influence of strain rate constitutive response of empty and foamed filled GSMST, the following conclusions are: (a) The compressive stress strain response of an empty and filled GSMST was found to depend on the applied the strain rate $0.01 / \mathrm{s}$ to $1 / \mathrm{s}$. (b) The deformation empty and foamed filled GSMST was found to be different in nature.

\section{References}

[1] S. Das, D.P. Mondal, N. Jha, A. Badkul, M.S. Yadav and P. Jain, "Effect of calcium addition on the microstructure and compressive deformation behaviour of 7178 aluminum alloy," Mater. Design., vol. 32, pp. 2803-2812, 2011. http://dx.doi.org/10.1016/j.matdes.2010.12.056

[2] D.K. Rajak, L.A. Kumaraswamidhas, and S. Das, " Energy absorption capacity of empty and foam filled mild steel tube under low strain rate at room temperature," Adv. Mater. Lett., vol. 6(6), pp. 548-553, 2015.

[3] L.J. Gibson, and M.F. Ashby, “Cellular solids: structure and properties," Cambridge University Press, UK, 528, 1997. http://dx.doi.org/10.1017/cbo9781139878326

[4] D.K. Rajak, L.A. Kumaraswamidhas, and S. Das,"Mechanical behaviour and energy absorption foam filled structures of square section under compression loading," Appl. Mech. Mater., Vol. 592-594, pp. 1109-1113, 2014.

http://dx.doi.org/10.4028/www.scientific.net/AMM.592-594.1109

[5] S. Das, A. Patel, and B.K. Prasad,"Compressive deformation of al (2014) - 10wt\%. sic composites: effect of strain rates and temperatures,"Mat. Sci. Eng. A., vol. 530, pp. 225-232, 2011.

http://dx.doi.org/10.1016/j.msea.2011.09.078

[6] N.B. Dhokey, V.A. Athavale, N. Narkhede, and M. Kamble,"Influence of mixing technique on sintering response of binary aluminium alloy powders," Adv. Mater. Lett., vol. 4(2), pp.164-168, 2013.

[7] S. Das, D.P. Mondal, N. Jha, A. Badkul, and R. Khedle,"High temperature compressive deformation behaviour of aluminium syntactic foam," Mat. Sci. Eng. A., vol.534, pp. 521-529, 2012.

http://dx.doi.org/10.1016/j.msea.2011.12.002

[8] R. Mittal, and D. Singh, “Dry sliding wear behaviour of spray formed ZrSio4 reinforced Al-Si-Sn alloy,”Adv. Mater. Lett., vol.3(1), pp. 38-41, 2012.

http://dx.doi.org/10.5185/amlett.2011.5258

[9] D.K. Rajak, L.A. Kumaraswamidhas, and S. Das, "Energy absorption capabilities of aluminium foam filled square tube," Adv. Mater. Lett., vol. 6(1), pp.80-85, 2015. 
[10]D.K. Rajak, L.A. Kumaraswamidhas, and S. Das, “An energy absorption behaviour foam- filled structures," Procedia Mater. Sci., vol. 5, pp. 164-172, 2014.

http://dx.doi.org/10.1016/j.mspro.2014.07.254 